\title{
AGENCY COST OF CREDIT ON MICROFINANCE INSTITUTIONS OF COOPERATIVE AND RURAL BANK TYPE
}

\author{
Purwanto \\ Lecture of Management Study Program STIE Trisna Negara Belitang \\ Email :dr.purwanto.mm@gmail.com
}

\begin{abstract}
Historically, most microfinance providers are in the form of cooperatives, while some policies studies recommend shareholders ownership because it can reduce the risk of capital costs and charges opportunism manager. This study aims to analyze the factors in the cost of ownership that distinguishes MFI with the type of cooperative ownership and village banks. The study was conducted by using secondary data from the MIX (Microfinance Information Exchange) market year 2007-2013. The factors Influencing the determinants of MFI ownership costs were Analyzed using multiple logistic regression analysis technique. The study found that the MFI of cooperative has advantages in operational efficiency and credit risk while village banks have advantages in the cost of customer service, cost of debt, cost of capital, social performance and financial performance
\end{abstract}

Keywords: Microfinance Institution, cooperatives, rural bank, agency cost of credit,.

\section{Introduction}

Microfinance Institutions (MFIs) are financial institutions serving the micro segment, which are generally poor people who have limited access to finance from formal financial institutions. The micro segment can be a business with a micro, small and medium scale in the industrial, trade, agricultural, urban and rural areas. The micro segment, which is generally the middle to lower economic community, has a high risk of credit services. Credit services in the micro segment have high information asymmetry due to generally unavailability of adequate financial reports, which increases risk at the credit screening, monitoring and control stages as well as the credit payment enforcement stage.

In microfinance institutions, agency problems and governance design are in accordance with the form of microfinance institutions. Historically, most microfinance providers have been in the form of cooperatives and donor agencies, while several policy studies have recommended forms of share ownership because they reduce the risk of capital costs and managerial opportunistic costs (Mersland, 2009). Cooperatives are still needed to reduce the risk of information asymmetry in markets with imperfect information (Mersland, 2009).

Cooperatives have advantages in group-based fund management where owners, managers, creditors and debtors are members. This will reduce information asymmetry and commitment in managing funds for the common welfare. However, the cooperative has a weakness on the scale of the business, because it is limited in collecting funds from third parties outside the group. On the other hand, the Village Bank has advantages in collecting third party funds, but it has weaknesses in the process of screening, monitoring and enforcing credit because 
the Bank and customers have interests and information that are not always the same (Dyrnes et al., 2015).

Cooperative-based MFI development will increase member loyalty because members are both borrowers of funds and owners of capital. Members as owners will support participation in MFI development in general. However, in practice cooperatives often operate like non-bank financial institutions and banks, namely low member participation. Village Bank-based MFIs provide the most complete financial service opportunities compared to existing financial institutions. Cooperative-based MFIs as a financial forum for members need to develop strategies in collecting member funds so that the institution can run well. Another alternative is a Village Bank with a cooperative owner, namely a Village Bank whose shares are owned by a company legally incorporated as a cooperative.

Comparison of cost of ownership (Mersland, 2009; Dyrnes et al., 2015), the effect of ownership type on economic and social performance (Abate et al., 2014; Mersland and Strøm, 2008; 2010; Simonsen, MS, Mersland, 2009), governance (Chakrabarty and Bass, 2014) have described previous research. However, these studies have not included credit risk factors based on ownership type. The management of credit agency problems in MFIs with cooperative ownership types and village banks can be different due to different organizational characteristics. This article re-examines the variables in previous research by including aspects of credit risk and discusses them again in the credit agency cost theory approach. Credit agency costs are viewed from the cost aspect to reduce credit agency problems and costs as a result of agency costs. The credit risk aspect is an important aspect to support the social performance and sustainability of an MFI.

\section{Literature Review}

Agency theory was first proposed by Jensen and Meckling (1976). The main principle of this theory states that there is a working relationship between the party giving the authority (the principal) and the party receiving the authority (the agent) in the form of a cooperation contract. The agency problem arises because of a conflict of interest between the principal and the agent, because the maximum utility does not meet between them. With regard to agency problems, positive accounting theory (Watts and Zimmerman, 1986) implicitly recognizes three forms of agency, namely: owner and management (bonus plan hypothesis), creditors to management (debt/equity hypothesis) and between government and management (political cost hypothesis).

Agency cost is an economic concept regarding the cost of the principal whether an organization, an individual or a group of people, when the principal selects or hires an "agent" to act on his behalf. The two parties have different interests and the agent has more information so the owner (principal) cannot directly ensure that the agent always acts in the best interest of the owner (principal). These costs consist of two main sources: the costs inherently associated with using the agent (for example, the risk that agents will use the organization's resources to their own advantage), and the costs of the techniques used to reduce the problems associated with the agent's use of information - further findings about what the agent does (for example, financial statements of production costs) or uses mechanisms to align agent interests with the principal (eg executive compensation with equity payments such as stock options) (Jensen and Meckling, 1976).

Agency costs in an MFI can be: 1) costs incurred by the principal to reduce agency problems, 2) costs as a result of agency problems. Regarding credit agency costs, the costs incurred by the principal to reduce agency problems include costs for credit monitoring control 
such as in the form of credit staff fees, administrative costs, operational costs. Costs as a result of agency problems are in the form of bad credit and inefficient company performance.

In microfinance institutions, agency fees can differ between several types of MFI ownership. According to Chakrabarty and Bass (2014) the ownership types of MFIs consist of cooperatives, village banks, non-bank financial institutions and NGOs. Cooperatives/Credit Units are financial credit institutions in the form of cooperatives to assist members by combining members' personal savings, providing mutual loans and providing other financial services. Village Banks are government sponsored / privately run banks that provide credit facilities to farmers, traders, or farmer cooperatives or merchant cooperatives for rural communities.

In an MFI in the form of a cooperative, the members of the cooperative are the owner (deposit capital or principal savings), the debtor (through mandatory and voluntary savings) as well as the creditor (borrower or user of funds). Agency problems arise between members as owners and management (who come from members as well), and owners and management (as debtors) with other members as creditors. In an MFI in the form of a bank, the owner (institutional capital) can be a third party or a different party from management, debtors and creditors. The micro community can play a role in ownership (shares), savings (as debtors) and users of funds (creditors). Agency problems arise between: 1) shareholders and management, 2) debtors and creditors, 3) majority and minority shareholders.

Cooperative-based MFIs have several strengths and weaknesses. Based on the concept of economic transaction costs (Coase, 1937, 1960; Williamson, 1975, 1985, 1996), cooperativebased MFIs have the advantage of better understanding borrowers than banks or other financial institutions. This is because the members and owners of the organization. Administrators and members know each other as part of the rural community. This will reduce asymmetry in credit screening, group-based monitoring and group-based credit default enforcement. Furthermore, cooperative institutions can effectively raise resources (assets) for self-help and selfdevelopment, reduce the risk of credit failure and support the sustainability of the institution.

The opposite point of view, based on the concept of agency costs (Jensen and Meckling, 1976; Fama and Jensen, 1983) identifies the institutional weaknesses of cooperatives. The management and cooperative members generally know each other. This will cause feelings of reluctance in credit screening, monitoring and enforcement of credit payments. The agricultural and market environment also places a high risk of agricultural activity. This condition can cause more credit extended to increase credit risk. On the other hand, the MFI market segment is generally too poor to save. This will cause limitations in raising internal resources for institutional independence. The greater the credit that is distributed can not easily help increase credit risk. Based on this description, it can be concluded that the greater the credit channeled does not necessarily support the sustainability of the institution.

Mersland (2009) explains that the cost of information asymmetry in cooperatives is, on average, lower than the cost of share ownership. The costs associated with controllingmonitoring of the MFI's nutmeg manager with share ownership type are better than those of cooperatives, but the costs associated with monitoring cooperative credit control are better than share ownership. Share ownership has a lower cost of capital ownership and supports the increase in MFI capital by attracting new investors into the MFI sector. However, the research results also show that cooperatives are more effective at reducing the cost of market contracts, and these results are particularly relevant because most microfinance organizations (MFIs) operating in markets are very inefficient. 
Mersland and Strom (2008) in addition to comparing the costs between several types of ownership also analyze the effect of agency costs based on ownership types on performance. Cost is defined as the sum of financial costs and transaction costs to clients, while performance is measured from cost performance, depth of coverage, service coverage, duration of service provision, scope and feasibility. Depth is defined as the client's poverty level or other social preferences such as the percentage of service to female clients. Service coverage is defined as the number of customers served. The duration of service provision and scope is defined as the number of financial contract types provided. Mersland and Strom (2008) also found that customer costs (cost of client), operational costs (operational costs), cost of debt (debt cost), and cost of capital (equity cost) differ between several types of MFI ownership.

In contrast to the research of Mersland and Strom (2008), other researchers found little evidence to suggest that the type of ownership affects operational efficiency. In a large European study, Iannotta et al. (2007) found that banks have higher profitability, but have higher operating costs than non-bank MFIs.

Simonsen and Mersland (2009) analyzed the effect of MFI ownership type on social performance. The study was conducted on 478 MFIs from 77 countries in the period 1996 to 2012. The type of ownership is more focused on NGOs with ownership of non-governmental organizations (NGOs) and company shareholders. The results of the study found that only the percentage of female customers has a significant effect on the cost of ownership. This may indicate that MFIs with NGO ownership have a higher average percentage of borrowing than share ownership. Meanwhile, other variables such as the depth of outreach to the poor were not significant between NGO ownership and share ownership. This also implies that profit (commercial) and non-profit orientations do not differentiate the service coverage of the poorest segments of society.

Dyrnes et al. (2015) analyzed the effect of ownership type on costs in MFIs. The study used panel data from 403 microfinance institutions in 74 countries. Data analysis used least squares regression analysis (OLS). This type of ownership focuses on non-profit cooperative organizations and shareholders. The results of the study found no significant differences in operating costs, employee costs or personnel productivity between non-profit MFIs and shareholders. The results of this study contradict the theory of cost of ownership and agency costs, which explain that organizations with share ownership have a lower cost of capital than non-profit companies. Another contradictory outcome of the anchovies is that MFIs with cooperative ownership should have lower operating costs, lower employee costs and labor productivity than MFIs that are shareholder-owned. This influence has in recent years been reduced by the inclusion of control variables.

Abate et al. (2014) analyzed the cost efficiency and outreach of services for the poor, including LKM. The analysis was carried out using a stochastic frontier approach in MFIs in Ethiopia. The results of the study found that it shows a trade-off between outreach to the poor and cost efficiency, indicating difficulty in trying to achieve two goals at once. MFIs with cooperative ownership type have better service coverage to the poor than MFIs that are owned by shareholders. According to Mersland (2009), cooperatives are less commercial and professional because they do not have owners with monetary incentives to monitor management. Conversely, share ownership has the benefit of being able to access more funds better than cooperatives.

Based on the description above, the hypothesis can be formulated as follows.

H1. Customer costs are lower for cooperative ownership type MFIs than for Village banks. 
H3. Debt costs are higher for cooperative ownership type MFIs than village banks.

H2. Operational costs are lower for cooperative ownership type MFIs than for Village banks.

H4. Capital costs are higher for cooperative ownership type MFIs than village banks.

H5. Social performance is higher for MFIs with cooperative ownership type compared to Village banks.

H6. Profitability performance is higher for MFIs with the Village Bank ownership type compared to cooperatives.

H7. Business sustainability is higher for MFIs with the Village Bank ownership type compared to cooperatives.

H8. Credit risk is higher for MFIs with cooperative ownership types than for Village banks.

\section{Research Method}

This reserach used secondary data, namely profiles and financial reports of 443 MFIs from 1998 to 2013 in 105 countries (Africa, Latin America, South and East Asia), which were collected from the Microfinance Information Exchange (MIX). The data source is the publication data of financial reports and MFI profiles published online at http://www.mixmarket.org.

Table 1. Variable and Measurement

\begin{tabular}{|c|c|}
\hline Variable & Operational Description \\
\hline \multirow[t]{2}{*}{ MFI Ownership Type } & Cooperative $=1$, Village Bank $=0$ \\
\hline & $\begin{array}{l}\text { Cooperatives/Credit Units are financial credit } \\
\text { institutions in the form of cooperatives to assist } \\
\text { members by pooling members' personal savings, } \\
\text { providing mutual loans and providing other financial } \\
\text { services "(CGAP, 1999). Village Banks are government } \\
\text { sponsored / privately run banks that provide credit } \\
\text { facilities to farmers, traders, or farmer cooperatives or } \\
\text { merchant cooperatives for rural communities (NSCB, } \\
\text { 2012). }\end{array}$ \\
\hline Customer Fees & Total Fees / Borrower \\
\hline Debt Costs & Total Expenses / Payable \\
\hline Operating costs & Operating Costs / Loan Portfolio \\
\hline Capital Costs & Natural Logarithm of Equity \\
\hline Social Performance & $\begin{array}{l}\text { Depth of Service }(\text { Outreach })=\text { Outreach } \\
\text { Poorest people }(3=\text { high, } 2=\text { medium } 1=\text { low })\end{array}$ \\
\hline Profitability Performance & Return on assets (ROA) \\
\hline Business Sustainability & $\begin{array}{c}\text { Operational self sufficiency: Operating Expenses / Operating } \\
\text { Income }\end{array}$ \\
\hline Credit Risk & $\begin{array}{l}\text { Portfolio at risk, Portfolios at risk > } 90 \text { days / Total } \\
\text { Loan Portfolio }\end{array}$ \\
\hline
\end{tabular}

Ownership costs between MFIs in the form of cooperatives and Village Banks are compared from the following aspects: customer costs (cost of clients), operational costs (operational costs), debt costs (debt cost), and capital costs (equity cost) and the impact of 
agency problems. The impact of agency problems is measured by the impact on credit risk, financial performance, social performance and the sustainability of the MFI. Social performance is measured from the outreach of services to the poor. The factors in agency costs that differentiate MFIs from the type of ownership of the Cooperative and Village Bank are analyzed in the logit function as follows:

$$
\begin{aligned}
& \log [p i /(1-p i)]=\alpha+\beta_{1} \mathrm{CONT}+\beta_{2} \mathrm{DEBC}+\beta_{3} \mathrm{OPC}+\beta_{4} \mathrm{CAP}+\beta_{5} \mathrm{REG} \\
& +\beta_{6} \mathrm{OR}+\beta_{7} \mathrm{NPL}+\beta_{8} \mathrm{ROA}+\beta_{9} \mathrm{SUS}+\varepsilon
\end{aligned}
$$

Where: $\alpha=$ constant, $\beta=$ regression coefficient, $\varepsilon=$ error factor (residual), $\mathrm{E}=\log [\mathrm{pi} /(1-\mathrm{pi})]=$ Log LKM with ownership of Cooperative (pi) or and Village Bank (1-Pi) ( binary: 1/0), CONT = Customer Costs, $\mathrm{DEBC}=$ debt costs, $\mathrm{OPC}=$ Operational Costs, $\mathrm{CAP}=$ Capital Costs, $\mathrm{REG}=$ regulated $/$ not, $\mathrm{OR}=$ Poor Community Service Coverage, NPL $=$ Bad Credit Risk for more than 90 days, ROA $=$ Return on Asset, SUS = LKM sustainability. To assess the accuracy of the regression function on the observed value, it can be seen from the goodnessfit value. The goodness of fit statistic can be measured from the statistical value of the Hosmer and Lemeshow Goodness-of-fit statistics and the coefficient of determination. The coefficient of determination (Cox and Snell's R Square and Nagelkerke's $\mathrm{R}^{2}$ ) is used to determine the percentage change in the dependent variable caused by the independent variable. Statistics Hosmer and Lemeshow Goodness-of-fit is a test of the significance of the equation used to determine how the independent variable affects the dependent variable (Y). If the Hosmer and Lemeshow Goodness-of-fit Statistics value is $>$ than 0.05 , it means that the model is able to predict its observation value or it can be said that the model is acceptable because it matches the observational data (Ghozali: 2007).

In logistic regression analysis, the interpretation of the calculation results will be carried out using the odds ratio or probability (probability). The logit model changes the dependent variable 1-0 (happens-does not happen) to be a probability that an event will occur or not occur (in this study are MFIs with cooperative ownership type and Village Bank). The logit model procedure will predict if the probability is $>0.5$ and predict it will not happen if the opposite is the probability $<0.5$ (Ghozali, 2010).

The assumption of data normality in binary logistic regression cannot be fulfilled because the $\mathrm{Y}$ value follows the noulli distribution, the variance value is a function of $\mathrm{p}$ (probability). Of course, in the data we have, this $\mathrm{p}$ value varies depending on the explanatory variable $\mathrm{X}$, because the $\mathrm{p}$ value varies, the variance value also varies so that the variance is heterogeneous. The weighted least squares approach can solve this problem. The Iteratively Reweighted Least Squares (IRLS) technique can be used as a method of choice other than the maximum likelihood (ML) method in estimating logistic regression model parameters. The maximum likelihood method is an alternative that can be used (Ghozali, 2010).

\section{Result And Discussion Result}

Based on table 2, it can be seen that in general village banks are better than cooperatives in financial performance (ROA), financial sustainability (Operational self-sufficiency), depth of service life (Outreach). Village banks are also better than cooperatives in terms of cost performance. The Village Bank has costs per borrower, cost of debt, operating costs), total costs 
International Journal of Economics, Business and Accounting Research (IJEBAR)

Peer Reviewed - International Journal

Vol-4, Issue-3, 2020 (IJEBAR)

E-ISSN: 2614-1280 P-ISSN 2622-4771

http://jurnal.stie-aas.ac.id/index.php/IJEBAR

and scale of service. One of the advantages of cooperatives is only in the aspect of personnel costs, which are lower than village banks.

Table 2. Descriptive Statistics

\begin{tabular}{lcccc}
\hline & \multicolumn{2}{c}{ Cooperative } & \multicolumn{2}{c}{ Village Bank } \\
\cline { 2 - 5 } & mean & stdev & mean & stdev \\
\hline Profitability Performance (ROA) & 0.011 & 0.077 & 0.030 & 0.031 \\
Business continuity & 1.166 & 0.658 & 1.242 & 0.259 \\
Social Performance & 1.299 & 0.625 & 1.592 & 0.772 \\
Credit Risk & 0.054 & 0.077 & 0.073 & 0.086 \\
Total Fees / Borrower & 224.8 & 558.9 & 106.2 & 166.6 \\
Total Expenses / Payable & 249.7 & 866.3 & 111.4 & 178.9 \\
Operating Costs / Loan Portfolio & 0.226 & 0.814 & 0.195 & 0.129 \\
Natural Logarithm of Equity & 0.089 & 0.132 & 0.103 & 0.065 \\
\hline
\end{tabular}

Source: MIX Market Data, 2007-2013

The results of the logistic regression equation on the factors that distinguish MFIs from the ownership of village banks and cooperatives (Table 3) obtained statistical LR values, each of which is significant at an error rate of $1 \%$. These results also show that together or simultaneously the factors in the model have a significant effect on differentiating MFIs from the ownership of village banks and cooperatives. The results of the regression equation obtained a value of $\mathrm{R}^{2}$ (McFadden $\mathrm{R}$-squared) of 0.228 or $22.8 \%$, which reflects that all independent variables are able to explain changes in the dependent variable by $22.8 \%$, while the rest is $77.2 \%$ influenced by other variables not involved. in this research model.

Tabel 3. Regression Test Summary

\begin{tabular}{crrrr}
\hline & \multicolumn{4}{c}{ Dependent Variable: } \\
\cline { 2 - 5 } C & \multicolumn{2}{c}{$p$} & exp \\
\hline CONT & -1.29 & $*$ ) & 0.092 & 0.275 \\
DEBC & 0.002 & $* * *)$ & 0.000 & 1.002 \\
OPC & 7.168 & $* * *)$ & 0.000 & 1,297 \\
CAP & -3.670 & $* * *)$ & 0.000 & 0.025 \\
OR & 1.726 & $* * *)$ & 0.000 & 5.618 \\
RISK & -0.650 & $* * *)$ & 0.000 & 0.522 \\
ROA & -2.832 & $* * *)$ & 0.000 & 0.059 \\
SUS & -7.882 & $* * *)$ & 0.000 & 0.001 \\
& -0.183 & & 0.208 & 0.833 \\
\hline McFadden R-squared & 0.228 & & & \\
LR statistic & 344.002 & & \\
Prob(LR statistic) & 0.000 & & \\
\hline
\end{tabular}

Note: $* * *$ ) level of significancy $=1 \%$, *) level of significancy $=10 \%$

Source: MIX Market Data, 2007-2013 
Based on the fit model analysis in the previous sub-chapter, the logistic regression equation used in this study is a logistic regression model that includes all variables (15 variables) in the research model as follows:

$\log [\mathrm{pi} /(1-\mathrm{pi})]=-1.29+0.002 \mathrm{CONT}+7.168 \mathrm{DEBC}-3.670 \mathrm{OPC} \quad 1.726 \mathrm{CAP}-0.650 \mathrm{OR}-$ 2.832RISK -7.882 ROA -0.183SUS

The results of hypothesis testing through the Wald test, from 9 (nine) independent variables, as many as 8 (eight) variables that have a significant influence in distinguishing cooperative form MFIs from village banks. In general, Village Banks have better financial performance (ROA), financial sustainability (Operational self-sufficiency), and depth of service coverage (Outreach) than cooperatives. Village banks also have lower customer service fees, debt costs and capital costs than cooperatives. Cooperatives have lower operating costs and credit risk than Village Banks. Business sustainability did not differ significantly between village banks and cooperatives.

Customer service cost (CONT) is a factor that has a significant influence in differentiating cooperative MFIs from village banks $(\mathrm{p}=0.000<0.01)$. The wald-test value of 0.002 means that the probability of customer service costs at cooperative MFIs is higher at $\mathrm{e} 0.002 \mathrm{I}=1.002 \mathrm{x}$ compared to village banks, provided that other variables are constant. A positive Wald-test value or an exponential value of more than 1 indicates that the cooperative has higher customer service costs than village banks.

The cost of debt (DEBC) is a factor that has a significant influence in differentiating MFIs from cooperatives and village banks $(\mathrm{p}=0.000<0.01)$. The wald-test value of 7.168 means that the probability of the cost of debt to a cooperative MFI is higher at e7.168 $=1.297 \mathrm{x}$ than a village bank, provided that other variables are constant. A positive Wald-test value or an exponential value of more than 1 indicates that the cooperative has higher debt costs than village banks.

Operational cost (OPC) is a factor that has a significant influence in differentiating MFIs in the form of cooperatives and village banks $(\mathrm{p}=0.000<0.01)$. The wald-test value of $-3,670$ means that the operational cost probability in cooperative-form MFIs is lower by e-3,670 = $0.025 \mathrm{x}$ compared to village banks, provided that other variables are constant. A negative waldtest value or an exponential value of less than 1 indicates that the cooperative has lower operating costs than a village bank.

The cost of capital (CAP) is a factor that has a significant influence in differentiating cooperative MFIs from village banks $(\mathrm{p}=0.000<0.01)$. The wald-test value of 1.726 means that the probability of the cost of capital in cooperative-form MFIs is higher at e1,726 = 5,618x compared to village banks, provided that other variables are constant. A positive Wald-test value or an exponential value of more than 1 indicates that the cooperative has a higher capital cost than a village bank.

Depth of Service Reach (OR) is a factor that has a significant influence in differentiating MFIs from cooperatives and village banks $(p=0.000<0.01)$. The wald-test value of 1.726 means that the probability of the cost of capital in cooperative-form MFIs is lower by e- $0.650=$ $0.522 \mathrm{x}$ compared to village banks, provided that other variables are constant. A negative waldtest value or an exponential value of less than 1 indicates that the cooperative has a lower depth of service coverage than a village bank.

Credit Risk (RISK) is a factor that has a significant influence in differentiating MFIs from cooperatives and village banks $(p=0.000<0.01)$. The wald-test value of $-2,832$ means that the probability of the cost of capital in cooperative-form MFIs is lower by e-2,832 $=0.059 \mathrm{x}$ compared to village banks, provided that other variables are constant. A negative wald-test value 
or an exponential value of less than 1 indicates that the cooperative has lower Credit Risk than village banks.

Profitability Performance (ROA) is a factor that has a significant influence in differentiating MFIs from cooperatives and village banks $(p=0.000<0.01)$. The wald-test value $-7,882$ means that the probability of the cost of capital in cooperative-form MFIs is lower by e$2.882=0.001 \mathrm{x}$ compared to village banks, provided that other variables are constant. A negative wald-test value or an exponential value of less than 1 indicates that the cooperative has a lower profitability performance than a village bank.

\section{Discussion}

The results of the study found that village banks have better financial performance (ROA), financial sustainability (operational self-sufficiency), and depth of service coverage (outreach) than cooperatives. Village Banks have advantages in accessing external sources of capital. Profitability is a measure to gain investor confidence and access external sources of capital. Shareholders provide incentives to monitor profits and this encourages village banks to have better financial performance. External capital also increases the scale of services to reach the poor. MFIs with the type of ownership of cooperatives or donor institutions also have limitations due to limited access to capital from the private sector and outside the regulation of the banking authority (C-GAP, 2003; Mersland, 2007; Mersland and Strom, 2007). MFIs with share ownership have several owners who are more knowledgeable about banking monitoring and operations, thus reducing the cost of monitoring opportunism managers. MFIs with shareholder firms also have the advantage of being able to be regulated by banking authorities, accepting deposits, providing a greater range of service quality, attracting equity capital from the private sector and benefiting from superior corporate governance because they are privately owned (Mersland , 2007; Mersland and Strom, 2007).

External capital increases the efficiency of economies of scale, so that the Village Bank also has a service fee per customer, a cost of debt per customer and a lower cost of capital compared to cooperatives. Another problem in cooperative-type MFIs is the ability of members to save. This places a limit on capital accumulation. Although the cost of customer service, the cost of debt per customer and the cost of capital in cooperatives is higher than that of village banks, cooperatives have lower operating costs and credit risk than village banks. This is due more to the fact that cooperatives are generally managed more simply than banks.

Apart from lower operating costs, MFIs in the form of cooperatives have advantages in terms of credit risk. The scope of services is limited, group-based loans support credit risk reduction. Lower lending also results in a lower credit risk impact.

In terms of business continuity, business continuity does not differ significantly between village banks and cooperatives. Even though it is supported by access to external capital, the profitability and services of village banks are in line with risks, so that it does not guarantee better business sustainability. On the other hand, the cooperative ownership type provides incentives for information asymmetry, but many cooperative members have low levels of education and limited knowledge of banking monitoring and operations. Members and administrators know each other to provide incentives for group monitoring and control credit risk, but the management's reluctance towards members makes monitoring control less effective. Therefore, even though members have personal incentives to monitor management, it does not guarantee business continuity (Mersland, 2007; Mersland and Strom, 2007). 


\section{Conclusion}

The results of the study found differences in the characteristics of credit agency costs in MFIs with the type of ownership of cooperatives and village banks. MFIs in the form of cooperatives have advantages in operational efficiency and credit risk, while village banks have advantages in customer service costs, debt costs, capital costs, social performance and financial performance. However, this study has limitations, because both MFIs in the form of cooperatives and village banks can overcome their respective weaknesses. Cooperatives can overcome external capital access constraints by involving partners (individuals or institutions) as members of the cooperative. Meanwhile, village banks can provide credit to group-based customers. The two hybrid mechanisms have not been discussed much in this study due to data limitations, so they become an important agenda for future research.

\section{REFERENCES}

Abate G.T., BorzagaC, Gernet K., 2014. Cost-Efficiency And Outreach Of Microfinance Institutions: Trade-Offs And The Role Of Ownership. International Development Vol. 26 No. 6: 923-932

Chakrabarty, S. dan Bass, A.E., 2014. Corporate governance in microfinance institutions: Board composition and the ability to face institutional voids. Corporate Governance: An International Review Vol. 22 No. 5: 367-386

Dyrnes, A., Mersland F., Berge, L.I.O., 2015. Cost of Ownership in Microfinance Institutions. Doctoral dissertations at University of Agder.

Fama, E. F. \& Jensen, M. C. 1983. Separation of ownership and control. The Journal of Law \& Economics, Vol. 26 No.2: 301-325.

Iannotta, G., Nocera, G. \& Sironi, A. 2007. Ownership structure, risk and performance in the European banking industry. Journal of Banking and Finance Vol. 31: 2127-2149.

Jensen, M. C., and W. H. Meckling., 1976. Theory of the Firm: Managerial Behavior, Agency Costs and Ownership Structure. Journal of Financial Economics Vol. 3 No.4 : 305-360.

Mersland, R., 2009. The Cost of Ownership in Microfinance Organizations. World Development Vol. 37 No.2: 469-478.

Mersland, R. \& Strøm, Ø. R., 2008. Performance and trade-offs in microfinance organizations Does ownership matter?. Journal of International Development, Vol. 20 No.4: 598-612.

Mersland, R. \& Strøm, Ø. R. 2010. Microfinance Mission Drift?. World Development, Vol. 38 No.1: 28-36.

Simonsen, M.S., Mersland, R., 2009. Effect of Ownership Types on the Social Performance in Microfinance Institutions. Doctoral dissertations at University of Agder.

Watts, R.L., Zimmerman, J.L., 1986. Positive Accounting Theory, Prentice-Hall Inc. 